\title{
IDENTIFIKASI KARAKTERISTIK RESPON PERTUMBUHAN GENOTIPE Moringa Olifera (L) TERHADAP CEKAMAN KEKERINGAN
}

\author{
Henny Diana Wati \\ ${ }^{1}$ Prodi Agribisnis, Fakultas Pertanian, Universitas Wiraraja,
}

\begin{abstract}
ABSTRAK
Tanaman Moringa Oleifera (L) dibudidayakan pada lahan kering yang pengairannya hanya mengandalkan dari curah hujan. Untuk mengantisipasi dampak buruk dari adanya cekaman kekeringan akibat kemarau panjang diperlukan strategi teknik budidaya yang tepat dan penggunaan varietas unggul Moringa Oleifera (L) yang toleran terhadap kekeringan. Sampai saat ini informasi tentang ketahanan tanaman Moringa Oleifera (L) masih sangat terbatas. Tujuan dari penelitian ini adalah untuk mengidentifikasi tingkat ketahanan beberapa genotype Moringa Oleifera $(\mathrm{L})$ terhadap cekaman kekeringan. Manfaatnnya diperoleh informasi kemungkinan adanya genotipe Moringa Oleifera (L) yang toleran terhadap kekeringan. Penelitian ini diharapkan nantinya dapat diperoleh genotipe Moringa Oleifera (L) di Kabupaten Sumenep yang toleran terhadap kekeringan. Hasil pengamatan pada umur 120 HST terlihat bahwa komponen pertumbuhan dan produksi biomas genotipe Moringa Oleifera $(\mathrm{L})$ A4. Berdasarkan data hasil pengamatan pertumbuhan, produksi dan pengujian ketahanan cekaman kekeringan mengindikasikan bahwa genotipe Moringa Oleifera (L) A4 paling toleran. Genotipe A4 diidentifikasi sebagai genotipe yang lebih toleran terhadap cekaman kekeringan dengan kandungan prolin 2,16. Oleh karena itu untuk pengembangan tanaman Moringa Oleifera $(\mathrm{L})$ di daerah yang sering terjadi cekaman kekeringan, menggunakan genotipe MoringaOleifera $(\mathrm{L})$ A4 dapat dianjurkan.
\end{abstract}

Kata kunci : Moringa Oleifera (L), Toleran, Cekaman Kekeringan

\section{PENDAHULUAN}

Cekaman kekeringan dapat diartikan suatu kondisi tanaman yang mengalami ancaman abiotik yang serius.

\footnotetext{
Alamat Korespondensi:

${ }^{1}$ Henny Diana Wati, Prodi Agribisnis, Fakultas Pertanian, Universitas Wiraraja. Jl. Raya Sumenep-Pamekasan Km. 5 PatianSumenep. Email: hennydianawati@yahoo.co.id
}

Situasi yang sama dialami oleh tanaman yang mengalami kurangnya ketersediaan air, meliputi presipitasi, dan jumlah kelembaban tanah dan distribusinya, selama siklus hidup tanaman berlangsung sehingga akan menyebabkan terhalangnya proses ekspresi genetik keseluruhan pada hasil panen. Cekaman kekeringan akan menjadi topik masalah yang harus diperhatikan dalam budidaya tanaman di lahan kering. Hal ini 
disebabkan karena tidak adanya jaminan adanya ketersediaan air sepanjang musim tanam, terutama musim menjelang kemarau. Tanaman yang terkena cekaman kekeringan akan secara perlahan-lahan akan mengalami berkurangnya proses pertumbuhan dan produktivitasnya juga akan mengalami penurunan. Cekaman kekeringan berpengaruh terhadap penekanan pola pertumbuhan dan perkembangan hasil tanaman, bahkan menyebabkan kematian pada tanaman tersebut. Penggunaan varietas unggul yang toleran terhadap cekaman kekeringan merupakan salah satu alternatif pilihan tenologi yang paling efektif dan efisien.

Budidaya tanaman kelor (Moringa oleifera) cukup dipelihara dengan sederhana, pemeliharaannya sangat minim, karena tanaman kelor cepat tumbuh berkembang, berbunga dan berbuah dalamsatu tahun sejak ditanam. Kemampuan tumbuh tanaman kelor cukup baik dan cara budidayanya yang mudah, oleh karena itu tanaman kelor dapat dibudidayakan di semua area di Indonesia. Salah satu sifat menguntungan dari tanaman ini adalah

pembudidayaannya membutuhkan penggunaan pupuk yang sangat minim dan jarang diserang hama serangga atau penyakit (mikrobiologis). Tanaman kelor (Moringa oleifera) yang berumur3 tahun dapat menghasilkan 400-600 polong/tahun dan pohon dewasa menghasilkan 1600 polong/tahun. Hasil produksi biomas tanaman kelor sangat dipengaruhi oleh musim, pemangkasan yang tinggi, dan interval pemangkasan.

Kebutuhan air yang dibutuhkan pada tanaman kelor dapat dipenuhi melalui tanah dengan jalan penyerapan oleh akar dari tanaman kelor. Partikel tanah memiliki kemampuan untuk mengikat air yang mempengaruhi besar kecilnya daya serap air oleh akar tanaman kelor. Tanaman kelor (Moringa oleifera) mempunyai akar yang kuat sehingga mampu meningkatkan penyerapan air dan toleran terhadap ketahanan kekeringan. Menurut Sammons et. al., 1980, dilihat dari sifat tanaman baik secara morfologi atau fisiologi, tanaman yang dapat dijadikan dasar penilaian dari sifat ketahanan kekeringan yaitu pola kedalaman akar, penyesuaian, jumlah dan lebar 
stomata, penyesuaian osmosis, serta peningkatan elastisitas dinding sel.

Pada umumnya tanaman Moringa Oleifera (L) dibudidayakan pada lahan kering yang pengairannya hanya mengandalkan dari curah hujan. Untuk mengantisipasi dampak buruk dari adanya cekaman kekeringan akibat kemarau panjang diperlukan strategi teknik budidaya yang tepat dan penggunaan varitas unggul Moringa Oleifera (L) yang toleran terhadap kekeringan. Sampai saat ini informasi tentang ketahanan tanaman Moringa Oleifera (L) masih sangat terbatas.

\section{METODE PENELITIAN}

\section{Jenis Penelitian}

Jenis penelitian ini merupakan penelitian percobaan yang dilakukan di Desa Poteran Kec. Talango Kab. Sumenep. Empat genotipe Moringa Oleifera (L) ditanam pada polibag dengan menggunakan ukuran panjang $20 \mathrm{~cm}$ lebar $20 \mathrm{~cm}$ dan tinggi $45 \mathrm{~cm}$ yang diisi tanah.Setelah ditanami semua polibag disiram dengan air sampai mencapai kapasitas lapang 100\%. Selanjutnya semua polibag semua pot diberikan perlakuan cekaman kekeringan dengan tidak memberikan penyiraman/pengairan sampai umur 120 hari, yang mana pada salah saat itu salah satu genotipe/nomor Moringa Oleifera (L) yang diuji dan paling peka terhadap cekaman kekeringan tidak mampu tumbuh normal. Pada saat umur 120 hari semua tanaman langsung dipanen. Metode ini mengacu pada metode skrining terhadap kekeringan yang telah dilakukan pada tanaman padi (Suardi, 2000).

\section{Analisis Data}

Penelitian percobaan ini dilaksanakan dengan menggunakan Rancangan Acak Kelompok dengan empat genotipe Moringa Oleifera (L) dan lima ulangan. Pengamatan komponen pertumbuhan dilakukan pada umur 120 HST meliputi tinggi tanaman, jumlah buku subur, dan panjang akar. Pengamatan komponen produksi dilakukan jugapada umur 120 HST meliputi bobot segar daun. Komponen yang berpengaruh terhadap ketahanan kekeringan yang diamati adalah panjang akar maksimum dan kadar prolin daun. Analisis kadar prolin 
Menurut Gazpersz (1994), dari tingkat penurunan dan model linier untuk Rancangan Acak pertambahan hasil biomas dari Kelompok adalah :

masing-masing pengamatan $\mathbf{Y} \mathbf{i j}=\mu+\sigma \mathbf{i}+\beta \mathbf{j}+\varepsilon \mathbf{i j}$ $\mathrm{i}=1,2,3,4 \mathrm{j}=1,2,3,4,5$ dalam hal ini :

Yij = nilai pengamatan

$\boldsymbol{\mu} \quad=$ nilaitengahpopulasi

$\boldsymbol{\sigma} \mathbf{i}=$ pengaruh aditif dari genotipe

$\beta \mathbf{j}=$ pengaruh aditif dari ulangan komponen yang diamati. Ketersediaan air pada tanaman kelor (Moringa Oleifera) yang terdapat di dalam tanah merupakan salah satu faktor lingkungan (abiotik) yang paling berpengaruh terhadap pertumbuhan dan produksi tanaman kelor (Moringa Oleifera).

Kebutuhan air pada tanaman घij = pengaruh galat percobaan

Data dari hasil pengamatan pertumbuhan dan produksi diolah berdasarkan analisis varian (Anova). Apabila data hasil analisis berbeda nyata maka dilanjutkan dengan uji pembedaan uji Duncan 5\%. Kadar prolin daun yang dianalisis merupakan komposit (gabungan) dari 4 ulangan sehingga tidak dilakukan analisis statistik.

\section{HASIL DAN PEMBAHASAN}

\section{Pertumbuhan Tanaman Moringa}

Oleifera (L)

Cekaman kekeringan umumnya menghambat pertumbuhan dan hasil produksi tanaman Moringa Oleifera (L). Hal ini dapat dilihat kelor (Moringa Oleifera) merupakan suatu pembatas utama untuk pertumbuhan tanaman dan produksi tanaman. Cekaman kekeringan sangat tidak di inginkan dan dapat membahayakan dalam budidaya tanaman kelor (Moringa Oleifera). Karena akan menghambat pertumbuhan dan produksi tanaman kelor (Moringa Oleifera). Cekaman kekeringan pada umumnya dapat menghambat pertumbuhan dan produksi hasil yang diamati dari besarnya tingkat penurunan karakter yang diamati akibat perlakuan cekaman kekeringan.

Setelah 120 hari ditanam pada tanah jenuh air tanpa penyiraman semua genotipe Moringa Oleifera (L) yang di uji tampak terlihat 
mengalami hambatan dalam pertumbuhannya dan gugurnya daun-daun tua. Adanya laju evapotranspirasi tanah menyebabkan tanaman Moringa Oleifera (L) mampu memperpanjang akarnya untuk mencari air.

Perlakuan uji cekaman kekeringan sangat berpengaruh sekali terhadap tinggi tanaman. Hal ini nampak jelas terlihat pada genotipe A4 menunjukkan pengamatan tinggi tanaman tertinggi. Seperti halnya pada pengamatan parameter tinggi tanaman, hasil pengamatan jumlah buku subur dan parameter berat daun per tanaman tertinggi juga diperoleh pada genotipe A4.

\section{Produksi Tanaman Moringa \\ Oleifera (L)}

Berdasarkan hasil uji statistik terlihat bahwa semua parameter komponen pertumbuhan dan produksi yang diamati berbeda nyata antar perlakuan genotipe yang diuji Tabel 1).

Tabel 1. Nilai F dari beberapa parameter pengamatan

\begin{tabular}{clcc}
\hline No. & Perlakuan & $\mathrm{db}$ & Nilai F \\
\hline 1 & Tinggi Tanaman & 3 & $10,957^{* *}$ \\
\hline 2 & $\begin{array}{l}\text { Jumlah Buku } \\
\text { Subur }\end{array}$ & 3 & $15,430^{* *}$ \\
\hline 3 & Panjang Akar & 3 & $5,061^{*}$ \\
\hline 4 & Berat Daun Segar & 3 & $5,890^{*}$ \\
\hline
\end{tabular}

Keterangan :

$$
\begin{aligned}
& *=\text { nyata } \\
& * *=\text { sangat nyata }
\end{aligned}
$$

Pada perlakuan cekaman kekeringan pada tanaman kelor (Moringa Oleifera (L.)) berpengaruh nyata terhadap semua komponen parameter. Tinggi tanaman dari ke empat genotipe yang di uji pada saat umur 120 HST sangat beragam yakni berkisar antara $84-117,6$ $\mathrm{cm} /$ tanaman.

Tabel 2. Pengaruh cekaman kekeringan terhadap komponen pertumbuhan beberapa genotipe Moringa Oleifera (L) pada umur 120 HST

\begin{tabular}{rrrrrr}
\hline No. & Perlk & Tinggi Tan & $\begin{array}{c}\text { Jumlah } \\
\text { Buku Subur }\end{array}$ & $\begin{array}{c}\text { Panjang } \\
\text { Akar }\end{array}$ & $\begin{array}{l}\text { Berat } \\
\text { Daun } \\
\text { Segar }\end{array}$ \\
\hline 1 & A1 & $84,6 \mathrm{bc}$ & $28 \mathrm{~b}$ & $26,8 \mathrm{bc}$ & $17 \mathrm{abc}$ \\
\hline 2 & $\mathrm{~A} 2$ & $91,8 \mathrm{~b}$ & $28,2 \mathrm{~b}$ & $27,8 \mathrm{~b}$ & $20 \mathrm{ab}$ \\
\hline 3 & $\mathrm{~A} 3$ & $84 \mathrm{bc}$ & $26 \mathrm{bc}$ & $25,8 \mathrm{bc}$ & $12,6 \mathrm{c}$ \\
\hline 4 & A 4 & $117,6 \mathrm{a}$ & $39,2 \mathrm{a}$ & $30,6 \mathrm{a}$ & $21 \mathrm{a}$ \\
\hline
\end{tabular}


Berdasarkan data hasil pengamatan uji duncan menunjukkan bahwa tinggi tanaman tertinggi dijumpai pada genotipe A4 yang tidak berbeda nyata dengan genotipe A2, A1 dan A4 (Tabel 2). Seperti halnya pada parameter tinggi tanaman hasil pengamatan komponen parameter panjang akar, jumlah buku subur juga diperoleh data tertinggi pada genotipe A4 kemudian diikuti oleh genotipe A2, A3 dan A4.

Hasil Pengamatan komponen produksi terlihat bahwa perlakuan cekaman kekeringan berpengaruh terhadap biomas khususnya berat segar daun Moringa Oleifera (L) dari empat genotipe yang di uji. Pada kondisi cekaman kekeringan yang cukup berat, parameter berat segar daun dari keempat genotipe $c$ yang diuji memiliki kisaran 12,6 - 21 gr/tanaman. Genotipe A4 terlihat masih mampu menghasilkan biomas paling tinggi mencapai 21 gr/tanaman.

Berat segar daun merupakan komponen utama produksi tertinggi dijumpai pada genotipe A4. Genotipe A4 mempunyai tingkat ketahanan yang paling tinggi terhadap adanya cekaman kekeringan.

\section{Kandungan Prolin terhadap Cekaman Kekeringan}

Mekanisme ketahanan kekeringan pada tanaman kelor Moringa Oleifera (L)terhadap cekaman kekeringan adalah kemampuan tanaman kelor Moringa Oleifera (L) untuk menghasilkan senyawa osmotikum yang berfungsi dalam proses penyesuaian osmotik, seperti prolin dan asam organik. Kadar prolin pada daun dari keempat genotipe Moringa Oleifera (L) yang diuji pada umur 120 HST sangat beragam berkisar antara 1,41\% $2,16 \%$ (Tabel 3).

Tabel 3. Kadar Proline Moringa Oleifera (L)

\begin{tabular}{cc}
\hline Perlakuan & Prolin $(\%)$ \\
\hline A1 & 1,55 \\
A2 & 2,04 \\
A3 & 1,41 \\
A4 & 2,16 \\
\hline
\end{tabular}

Hasil analisa kadar prolin tersebut terlihat pula bahwa genotipe A4 mampu menghasilkan kadar prolin lebih tinggi dibandingkan dengan genotipe yang lain. Farooq et al. (2009) menyatakan bahwa untuk menjaga potensial air pada tanaman, diperlukan peningkatan kadar 
senyawa osmotikum seperti asam amino prolin dan asam organik.

$$
\text { Perlakuan }
$$

cekaman

kekeringan pada genotipe Moringa Oleifera (L) akan menyebabkan terjadinya akumulasi prolin pada jaringan tanaman pada semua genotipe Moringa Oleifera (L) yang di uji. Data pengamatan kandungan prolin pada beberapa genotipe Moringa Oleifera (L) yang diteliti disajikan pada tabel 3. Genotipe A4 mempunyai kemampuan mengakumulasi prolin yang lebih tinggi, disusul dengan genotipe A2. Genotipe A1 mempunyai kemampuan mengakumulasi prolin yang paling rendah disusul dengan genotipe A3. Sehingga genotipe A4 mempunyai tingkat ketahanan yang paling tinggi terhadap adanya perlakuan uji cekaman kekeringan.

\section{KESIMPULAN DAN SARAN}

\section{Kesimpulan}

Tingkat ketahanan dari empat genotipeMoringa Olifera (L) yang diuji terhadap Cekaman Kekeringansangat beragam. Komponen pertumbuhan dan produksi tertinggi di antara genotipe yang diuji pada kondisi cekaman kekeringan dijumpai pada genotipe 4. Kadar prolin tertinggi juga diperoleh pada genotipe A4 dan genotipe A2 dengan kandungan prolin masing - masing 2,16 dan 2,04. Sehingga genotipe A4 diidentifikasi sebagai genotipe yang lebih toleran terhadap cekaman kekeringan dibandingkan genotipe A1 dan genotipe A3.

\section{Saran}

Saran yang diperoleh pada penelitian ini, perlu adanya penelitian lebih lanjut tentang pengendalian hama dan penyakit yang menyerang tanaman Moringa Olifera (L). 


\section{DAFTAR PUSTAKA}

Bose, C.K., 2007, Possible role ofMoringa Oleifera L.root in epithelial ovarian cancer, MedGenMed, 9(1): 26.

Farooq, M./ A. Wahid, N. Kobayashi, D. Fujita, and S.M.A. Basra. 2009. Plant drougth stress:effect, mechanisms, and management. Agron. Sustain. Dev.29 (2009) : $185-212$.

Gasperz, V. 1994. Metode Perancangan Percobaan. CV. Armico. Bandung.

Gembong, Tjitroesoepomo. 1989. Morfologi Tumbuhan. Gajah Mada University Press.Yogyakarta:

Jones, M.M. and N.C. Turner. 1980. Osmotic adjustment in expanding and fully expanded leaves of sunflower in response to drought deficit. Proc. Indian. Nat. Sci. Acad. 3 (57) : 288304.

Kramer, J.P. 1980. Draught Stess and The Origin of Adaptation. In Turner, Kramer (eds) Adaptation of Plants to Water and High Temperature Stress. John Willey and Sons. Canada.

Mathius, N. T., Liwang, T., Danuwikarsa, M. I., Suryatmana, G., Djajasukanta, H., Saodah, D. dan Astika, I. G. P. W. 2004. Respons Biokimia Beberapa Progeni Kelapa Sawit (Elaeis guineensis Jacq.) Terhadap

$\begin{array}{lr}\text { Cekaman } & \text { Kekeringan Pada } \\ \text { Kondisi } & \text { Lapang. } \\ \text { Penelitian } & \text { Balai } \\ \text { Perkebunan } & \text { Indonesia, } \\ \text { Bogor.http://www.ipard.com/in } \\ \text { fopstk/ publikasi/e- } \\ \text { jurnal/biotek/mp72-02-01.pdf. }\end{array}$

Pitono, J., H. Nurhayati, dan Setiawan. 2008. Seleksi ketahanan terhadap stres kekeringan pada tiga nomor somaklon nilam di lapangan. Laporan Teknis Penelitian TA. 2008. Balittro. (tidak dipublikasikan). hal. 201-212.

Salisbury, F.B. and C.W. Ross. 1995. Fisiologi Tumbuhan. Jilid I. Bandung : Penerbit ITB, Bandung. 241 hal.

Sammons DJ, Peters DB and Hymowitz T. 1980. Screening Soybeans for Tolerance to Moisture Stress : a Field Crops Res 3:321-335

Suardi, D. 2000. Kajian Metode Skrining pada Toleran Kekeringan. Buletin Agro Bio. 3 (2) : 67-73.

Yoshida, Y., T. Kiyosue, K. Y. Shinozaki, and K. Shinozaki. 1997. Regulation of levels of proline as an osmolyte in plants under drought stress. Plant Cell Physiology. 38 (10) : 1095-1102. 